\title{
Composition as A Way of Forming the Terms of Medical Instruments and Surgical Devices in Modern Chinese
}

\author{
Lola Akmalovna Sultanova \\ Senior Lecturer Faculty of Sinology, Department of Chinese Philology TSUV, Tashkent, Uzbekistan
}

\begin{abstract}
Studying any foreign language, involves a detailed study of all its aspects including Chinese. Medical instruments and equipment are one of the most significant components of contemporary medicine. 构词法 gòucifă-word formation is the process of creating new words based on existing language units.

In this aspect, word formation is considered as one of the most significant means in replenishing the vocabulary of the language. New words in a language are formed according to certain rules, models and schemes - according to certain patterns, which form a certain linguistic mechanism, which is called word formation. As a result of compounding, complex words are formed, between the components of which there are usually similar relationships, the basic models of compounding are developed in the works of A.I. Ivanov and E.D. Polivanov, I.M. Oshanin, V.M. Solntsev, N.N. Korotkov, as well as in the works of such Chinese linguists as Lu Zhiwei, Zhang Shoukang, Ren Xuelyang, and others. In this article, we give examples of the structural models of word formation of Lu Zhiwei.
\end{abstract}

KEYWORDS: word formation, compounding, medicine, term, surgical instruments

\section{INTRODUCTION}

Learning any foreign language, involves a detailed study of all its aspects including Chinese.

Terminology in the conditions of acceleration of scientific and technological progress acquires special significance. It is a source of information, a tool for mastering a specialty. Any field of science and technology finds its expression in terms. There is practically not a single area of knowledge that could be studied without knowing the terminology.

The scientific description of various terminologies as thematic and lexical-semantic systems, the study of their semantics and structure has always been and remains one of the most significant tasks of modern linguistics.

Every country needs medicine, just like every person needs treatment. Therefore, medical instruments and equipment play a significant role in the life of people and society. All modern hospitals, without exception, have medical instruments and equipment. Medical instruments and equipment are one of the most significant components of modern medicine. As important as the correct diagnosis is made, it is equally significant to use the appropriate medical equipment. Often, the presence of such equipment directly determines the correct diagnosis - and this is already half of the treatment. China is a manufacturer of high quality surgical instruments and equipment used in ophthalmology, neurosurgery, heart and vascular surgery - wherever high precision is required. More than 100 countries of the world cooperate with the PRC in this area. Much attention is paid to the implementation of the experience of world medical science, because China now imports from the West scientific ideas, technical achievements, and equipment. These factors determined the relevance of this article.

In this regard, the study of term systems of typologically different languages is of great scientific interest. The definition of similarities and differences in the terminology of typologically different languages is especially necessary to establish the forms of commonality and divergence; in a practical aspect - to create certain prerequisites for solving a number of problems of interlanguage terminological work.

The relevance of this article is also determined, first of all, by the theoretical and practical significance of research in the field of terminology. Despite the considerable number of available works, the linguistic aspect of the study of terminological vocabulary still needs in-depth research.

The object of our research is the layering of the terms of instruments and devices of general surgery in modern Chinese.

The purpose of our work is to consider the way of word composition as the formation of terms denoting medical instruments 


\section{Composition as A Way of Forming the Terms of Medical Instruments and Surgical Devices in Modern Chinese}

and devices for general surgery in modern Chinese.

\section{THEORETICAL VALUE}

This work supplements and expands the available information about medical terms and phrases, about general trends that characterize the methods of term formation in Chinese terminology.

In linguistic science, the term word formation itself is ambiguous. It is customary to refer to them as various linguistic phenomena. Word formation (构词 法 gòucífă) is most often understood as the process of creating new words based on existing linguistic units.

In this aspect, word formation is considered as one of the most important means of replenishing the vocabulary of the language. New words in a language are formed according to certain rules, models and schemes - according to certain patterns, which form a certain linguistic mechanism, which is called word formation.

However, the term word formation denotes a section of linguistics that publishes the processes of formation of derivative words, their structure, as well as the system into which they are included.

The main tasks of word formation as a branch of linguistics are as follows:

1) Establish whether the word is a derivative in the modern language (at the synchronic level);

2) Determine from what and with the help of what a given derivative word is formed Degree of study: The system and methods of word formation of the Chinese language, as noted by A.A. Khamatova [1. 56-77], was repeatedly the subject of analysis of many works of the linguistic content of both Russian and Chinese scientists: E.D. Polivanova, I.M. Oshanina, A.A. Dragunova, N.N. Korotkova, S.E. Yakhontova. V.M. Solntsev describes in detail such methods of word formation as conversion, compounding, affixation [2. 204]. V.I. Gorelov distinguishes lexical-semantic, lexical-morphological, morphological, morphological-syntactic, morphological-phonetic, lexical-semantic, reduplication and contraction in Chinese [3. 19-20]. Considering the issues of nominal word formation of terms, O.P. Frolova singles out morphological, syntactic, phonetic methods and conversion [4. 22].

I. D. Klenin in collaboration with V.F. Shichko examines morphological, semantic, phonetic, affix word formation, analyzing in detail morphemic contraction and its types [5. 72-110]. Li Jinxi [6. 84-86] and Liu Shiju distinguish three main ways of word formation: syntactic, morphological and phonetic [7. 518-519]. Another classification is offered by the author of "Lexicology of the Chinese language" Sun Changxu. He subdivides the methods of word formation in the Chinese language into: phonetic, semantic, structural, further subdivided into lexical-structural and morphological-structural [8. 78-79]. Ren Xueliang gives a different classification of the ways of forming words in modern Chinese from the above. He identifies five main ways of forming new words: morphological, syntactic, stylistic, phonetic and synthetic [9. 2].

From the above, we can conclude that in the Chinese language there are various ways of forming new words: compounding (basic composition), affixation, semi-affixation, reduplication, morphemic contraction, conversion, phonetic processes, and the disintegration of polysemy. The study of the word-formation model goes through a grammatical and semantic analysis of already created words and explains the way of combining morphemes in an intraword structure.

As a result of compounding, complex words are formed, between the components of which there are usually similar relations, as rightly pointed out by such linguists as: I. M. Oshanin, V. M. Solntsev, M. K. Rumyantsev, N. N. Korotkov, N. V Solntseva, A. L. Semenas, Wang Dechun, Wang Li, Lu Shusiang, Guo Shaoyu, etc.

Traditionally, scientists distinguish five derivational models: compositional (copulative), attributive (attributive), verbal-object, subjective-predicative, and productive.

The main word composition models were developed in the works of A.I. Ivanov and E.D. Polivanov [10. 304], I.M.Oshanin [11. 433], V.M. Solntsev [12. 204], N.N. Korotkov [13. 400], as well as in the works of such Chinese linguists as Lu Zhiwei [14. 164], Zhang Shoukang [15. 90-113], Ren Xuelyang [16. 290] et al. In this article, we will give examples of the structural models of word formation by Lu Zhiwei.

Lu Chzhiwei in the monograph "Word formation in the Chinese language" [17. 15-55] examines nominal word formation according to five derivational models. In the course of the analysis, we found that the terms denoting general surgical instruments are formed according to three types - attributive, copulative and verb-object.

Lu Zhiwei identified five structural models of word formation, built according to the definitive (attributive) type:

1. Noun + noun:

缝针 féng zhēn (suture + needle) _ suture needle;

解剖刀 jiě pǒu dāo (autopsy + knife) - anatomical knife, scalpel

截断刀 jiéduàn dāo (amputation + knife) - amputation knife 


\section{Composition as A Way of Forming the Terms of Medical Instruments and Surgical Devices in Modern Chinese}

2. verb + noun:

刮刀 guādāo- нож для выскабливания (刮- scrape, shave + 刀 knife)

通针 tōng zhēn (lead, go + needle) - stiletto

3. adjective + noun

直刀 zhí dāo - straight knife (straight + knife)

尖钻头 jiān zuàntóu (sharp + drill) - sharp drill

4. numeral + noun:

七星针 qīxīng zhēn - seven-needle instrument (七- seven +星- star +针- needle)

三角缝针 sānjiǎo féng zhēn (three + angle + suture needle) - cutting needle

三弯钳 sān wān qián (three + beaten, fold, curvature + clamp) - angular clamp

5. Pronoun + noun

For the Chinese terminology, the first four were productive. The fifth pattern was not marked. According to the copulative type, Lu Zhiwei identified four structural models:

1. noun + noun:

铌剪 niè jiăn (tweezers + scissors) - scissors - forceps

剪刀 jiăndāo (scissors + knife) - scissors

铌夹 niè jiā (tweezers + clamp, clamp, bracket) - tweezers holder

器械钳 qixiè qián (instrumentation + forceps) - instrumental forceps

钳夹 qián jiā (pliers + clamp, retainer, staple) - pliers holder

2. verb + noun:

拉钩 lāgōu (pull + hook) - retrakgor, hook

探针 tàn zhēn (explore + needle) - probe

3. adjective + noun:

平镊 píng niè (smooth, smooth + tweezers) - smooth tweezers

长摄 zhăng shè (long + tweezers) - long tweezers

细解剖铌 xì jiěpōu niè (thin + anatomical forceps) - thin anatomical forceps

弯剪 wān jiăn (curved + scissors) - curved scissors

4. adjective + verb

The fourth pattern was not marked.

By verb-object type:

拔毛铝 bá máo niè (pulling + hair + tweezers) - hair removal tweezers

植毛针 zhímáo zhēn (plant + hair + needle) - hair transplant needle

摇钻 yáo zuàn (swing, wobble + drill, boron) - hand drill

止血夹 zhǐxiě jiā (stopping + blood + brace) - hemostatic clips, hemostat

Brackets

抽髓针 chōu suǐ zhēn (remove, extract + bone marrow + needle) - drill

\section{CONCLUSION}

We came to the following conclusion, having considered these models of word formation: Chinese terminology is mainly formed by adding according to the attributive type, the terms of the copulative type also make up a significant part, and the terms of the verb-object type are represented by an in significant amount.

Composition occupies a dominant position and plays a leading role in the system of Chinese word formation. This is explained by the exceptional productivity of word composition, which, both in the past and now, is the main way for the Chinese language to create new words.

\section{REFERENCES}

1) A.A. Khamatova Word formation of the modern Chinese language. Publishing house "Ant" M., 2003., -p. 56-77

2) Solntsev V.M. Essays on the modern Chinese language. Moscow: 1957, -p. 204

3) V.I. Gorelov Lexicology of the Chinese language. Publishing house "Education" Moscow: 1984., -p. 19-20 


\section{Composition as A Way of Forming the Terms of Medical Instruments and Surgical Devices in Modern Chinese}

4) Frolova O.P. Word formation in the terminological vocabulary of the modern Chinese language. Publishing house "Science" Novosibirsk, 1981, -p. 22

5) Klenin I.D., Shichko V.F. Lexicology and phraseology of the Chinese language. Moscow: 1978. -p. 72-110

6) Li Jinxi. Hanyu goucyfa hetsybyao yanjiu [Study of word formation and vocabulary of the Chinese language] // Beijingshi fanda syuexuebao [Bulletin of the Beijing Pedagogical University]. 1959, -p. 84-86

7) Li Jinxi, Liu Shiju. Hanyu yufa jiaotsai [Teaching materials on Chinese grammar] Beijing, -pp. 518-519

8) Sun Changxu. Hanyuitsyhui [Chinese vocabulary] Changchun, 1956, -p. 78-79

9) Ren Xueliang. Hanyu zaotsifa [Word formation of the Chinese language] Pe-kin, 1981, -p. 2

10) Ivanov A.I., Polivanov E.D.Grammar of the modern Chinese language. Moscow: 1930. -p.304

11) Oshanin I.M. Word and parts of speech in Chinese: Day. .... doct. philol. on-uk. Moscow: 1946, -433.

12) Solntsev V.M. Essays on the modern Chinese language. Moscow: 1957. -p.204

13) Korotkov N.N. The main features of the morphological structure of the Chinese language. Moscow: 1968, -p. 400

14) 陆志韦。汉语的构词法。北京。科学出版社。1964. -p. 164

15) Zhang Shoukang. Guanyu hanyu goutsyfa [On word formation of the Chinese language] // Yufaheyuifatzyaoxue [Grammar and teaching grammar]. Pe-kin: 1956, -p. 90-113.

16) Ren Xueliang. Hanyu zaotsifa [Word formation of the Chinese language] Pe-kin: 1981,- p. 290

17) 陆志韦。汉语的构词法。北京。科学出版社。1964pp.15-55. 